\title{
RELATION BETWEEN RADIOCARBON, ARCHAEOLOGICAL DATING AND SEDIMENT PROPERTIES ON THE EXAMPLE OF COLLUVIAL DEPOSITS (NE POLAND)
}

\author{
EWA SMOLSKA \\ Faculty of Geography and Regional Studies, University of Warsaw, \\ Krakowskie Przedmieście 30, 00-927 Warsaw, Poland
}

Received 15 June 2010

Accepted 15 March 2011

\begin{abstract}
This study focuses on the analysis of the structural and textural features of the colluvial (deluvial) deposits in the Suwałki Lake District (NE Poland) and their absolute age. The colluvium has a thickness of up to $150 \mathrm{~cm}$. The dates of the peat under colluvium or lowermost fossil humusrich horizons point to the ages from $5405 \pm 80 \mathrm{BP}$ to $480 \mathrm{BP}$. Deposition of material at the footslope is a result of a denudation triggered by human action (surface water erosion and tillage erosion) and usually corresponds with the settlement stages. The ${ }^{14} \mathrm{C}$ dating of deposited sediment sometimes indicated to older dates of colluvium then the archaeological evidence available for examined sites. Locally, the overlying fossil humic horizon was older then the lowermost one. The textural features of the colluvial deposits such as: the content of fine fraction, weak sorting and relationship between the mean grain-size $(\mathrm{Mz})$ and the sorting index $\left(\sigma_{1}\right)$ were used to recognize sediment redeposited from the upper part of the slope. Basing on the mineral composition and electrical conductivity of fossil humus horizon it is possible to say whether the soil was degraded or aggraded. These features of the humusrich horizons occurring between colluvial sediments can be used to explain discrepancy between the radiocarbon dating and archaeological evidence.
\end{abstract}

Keywords: colluvium, fossil soil, sedimentological features, radiocarbon dating, settlement, NE Poland.

\section{INTRODUCTION}

Finding correlation between stages of slope erosion and archaeological data is very important when analysing colluvial deposits originated from soil erosion (deluvium). Human settlement of the research area, followed by forest clearance and introduction of agriculture, triggered water soil erosion on slope and redeposition at footslopes and in dry valleys (Starkel, 1988, 2005; Bork, 1989; Klimek, 2003; Zolitschka et al., 2003; Wilkinson, 2003). Numerous studies show a good correlation between radi-

Corresponding author: E. Smolska

e-mail: e.smolska@uw.edu.pl

ISSN 1897-1695 (online), 1733-8387 (print)

(C) 2011 Silesian University of Technology, Gliwice, Poland.

All rights reserved. ocarbon age of colluvium and settlement stages (Sinkiewicz, 1993, 1998; Twardy, 2002; Lang, 2003). However, in certain morphological situations there are discordances between absolute age of the slope deposits and age of the culture horizon (Śnieszko 1991, 1995; Smolska 2003; Bluszcz et al., 2007).

Difficulties in proper dating of the slope deposits have been reported (Pazdur MF, 1995; Bluszcz et al., 2007; Pazdur A, 2007). The studies emphasized the role of numerous parts of slopes as source areas, the role of different fragments of small catchments and the fact that the slope deposits undergo multi-stage redeposition at footslopes and on floors of depressions or dry valleys. Local- 
ly, layers of the slope deposits can be arrange in an inverted sequence, and sometimes impossible to date due to admixtures of humic matter of different age. Sinkiewicz (1998) and Lang and Hönscheidt (1999) elaborated a scheme of redeposition of the slope deposits.

The previous research on slope deposits conducted in the Suwałki Lakeland in NE Poland focused on the thickness, lithology and age of the deposits (Smolska, 2005, 2007). Selected sedimentological features were analysed and correlated with settlement stages (Smolska, 2003, 2005; Smolska and Szwarczewski, 2009). The aim of this article is to analyse relations between features of the colluvium, settlement stages and radiocarbon age of the deposits. Particular attention was paid to indicative features which allow inferring about the course and dynamics of geomorphological processes during deposition of the colluvial units (sediment layers). Particular attention was paid to sedimentological features allowing to infer about the course and dynamics of agradation-degradation processes. This was especially important when radiocarbon dating disaccorded with archaeological data.

\section{METHODS}

Thickness and lithology of colluvial deposits were determined in pits and shallow drillings at the footslopes. Sedimentary units were determined in the field and for each unit granulometric analysis was performed with use of sieves and a settling tube. The organic matter content was determined based on loss on ignition. Electrical conductivity was checked in selected vertical profiles, and content of heavy minerals was checked in selected samples.

Granulometric indices: the mean grain size diameter $(\mathrm{Mz})$, standard deviation $\left(\sigma_{1}\right)$ and skewness $\left(\mathrm{Sk}_{1}\right)$ were calculated based on Folk and Ward (1957) formulae, and the weathering index (W) based on Racinowski and Rzechowski (1969).

The age of the slope deposits was determined based on radiocarbon dating of peat found under the colluvium and humus-rich layers or buried soil horizons occurring within the colluvium (Table 1). Radiocarbon age was calibrated with CALIB REV. 4.2.2 (Stuiver and Reimer, 1993) and calibration curve IntCal04 (Reimer et al., 2004).

Archaeological and historical data pertaining to human settlement were also analysed.

\section{STUDY AREA AND SETTLMENT HISTORY}

The Suwałki Lakeland is characterized by a postglacial relief, typical for the last-glaciation (Weischelian) areas. Undulating and hummocky ground moraine surface prevail in the area. There are numerous hills of terminal moraine and dead ice moraines. Wide depression developed in the area due to glacial erosion and dead ice melt-out. Floors of the depressions are marked with aerial deglaciation landforms. Subglacial tunnel valleys are also frequent.

Table 1. Age and thickness of study colluvial deposits at footslopes.

\begin{tabular}{|c|c|c|c|c|c|c|}
\hline \multirow{2}{*}{ No } & \multirow{2}{*}{$\begin{array}{l}\text { Location } \\
\text { of slope }\end{array}$} & \multirow{2}{*}{ Relief } & \multirow{2}{*}{$\begin{array}{l}\text { Thickness of human } \\
\text { induced colluvium }\end{array}$} & \multirow{2}{*}{$\begin{array}{c}\text { Type of dated } \\
\text { material }\end{array}$} & \multicolumn{2}{|c|}{ Age of human induced colluvium } \\
\hline & & & & & $\mathrm{BP}$ & Cal. (range $68 \%$ ) \\
\hline 1 & Łopuchowo 1 & kame hill & $55 \mathrm{~cm}$ & soil & $\begin{array}{c}3160 \pm 70 \\
\text { Ki-7962 }\end{array}$ & 1523-1367 BC \\
\hline 2 & Łopuchowo 2 & kame hill & $80 \mathrm{~cm}$ & soil & $\begin{array}{l}2740 \pm 70 \\
\text { Ki-10281 }\end{array}$ & $945-808$ BC \\
\hline 3 & Prudziszki 1 & hill of moraine & $70 \mathrm{~cm}$ & organic mud & $\begin{array}{l}2500 \pm 90 \\
\text { Ki-10362 } \\
\end{array}$ & $790-510 \mathrm{BC}$ \\
\hline 4 & Prudziszki 2 & hill of moraine & $65 \mathrm{~cm}$ & peat & $\begin{array}{l}5405 \pm 80 \\
\text { Ki-10280 }\end{array}$ & $3340-3220$ BC \\
\hline 5 & Udziejek 1 & valley side & $95 \mathrm{~cm}$ & soil & $\begin{array}{l}1650 \pm 60 \\
\text { Ki-7963 }\end{array}$ & $336-440$ AD \\
\hline 6 & Udziejek 3 & valley side & $80 \mathrm{~cm}$ & organic mud & $\begin{array}{l}1310 \pm 60 \\
\text { Ki-10366 }\end{array}$ & $661-728 \mathrm{AD}$ \\
\hline 7 & Gulbieniszki & hill of moraine & $110 \mathrm{~cm}$ & soil & $\begin{array}{c}1160 \pm 100 \\
\mathrm{Ki}-7961 \\
\end{array}$ & 776-982 AD \\
\hline 8 & Gulbin & slope of depression & $80 \mathrm{~cm}$ & organic mud & $\begin{array}{l}1070 \pm 70 \\
\text { Ki-10366 }\end{array}$ & $661-728$ AD \\
\hline 9 & Gulbin & slope of depression & $55 \mathrm{~cm}$ & peat & $\begin{array}{c}380 \pm 35 \\
\mathrm{GdA}-1722 \\
\end{array}$ & $1450-1516$ AD \\
\hline 10 & Potasznia & valley side & $20 \mathrm{~cm}$ & organic mud & $\begin{array}{l}1005 \pm 70 \\
\text { Ki-10726 } \\
\end{array}$ & $977-1098$ AD \\
\hline 11 & Kamenduł & kame terrace & $90 \mathrm{~cm}$ & peat & $\begin{array}{l}860 \pm 130 \\
G d-10869\end{array}$ & $1150-1264$ AD \\
\hline 12 & Smolniki & slope of depression & $75 \mathrm{~cm}$ & soil & $\begin{array}{l}460 \pm 70 \\
\text { Ki-7964 }\end{array}$ & $1420-1560 \mathrm{AD}$ \\
\hline
\end{tabular}


Denivelations are moderate and reach $15-30 \mathrm{~m}$, and only locally exceed $50 \mathrm{~m}$. Slopes are inclined from $6^{\circ}$ to $18^{\circ}$ and have convex-concave or straight shapes. Locally, there are dry valleys or gullies developed on the slopes.

The Suwałki Lakeland lies in the temperate continental climatic zone with annual precipitation from $464 \mathrm{~mm}$ to $783 \mathrm{~mm}$, and the mean annual air temperature $4.4^{\circ}-7.8^{\circ} \mathrm{C}$.

The region was first settled by farmers, the Balts, about 700 BC (Brzozowski et al., 1993; BitnerWróblewska, 1998). Forest clearance proceeded slowly. At the beginning of the mid-Subatlanic period the deforestation with a slush-and-burn method covered up to 5$7 \%$ of the region (Stasiak, 1965, 1971), therefore anthropogenic soil erosion could occur only locally. Significant development in agriculture and crafts started at the beginning of the Middle Ages and is associated with the Jatvings. Stabilization of the settlement network occurred during in-migration from Lithuania and Masovia in $15^{\text {th }}$ and $16^{\text {th }}$ centuries.

Colluvial deposits were researched in the central part of the Suwałki Lakeland as well as in its north-western and southern parts (Fig. 1).

\section{RESULTS AND DISCUSSION}

\section{Features of colluvial deposits and their age}

Colluvial deposits found at footslopes are usually 0.5 to $1.5 \mathrm{~m}$ thick, however, in places maximum thickness reach $1.8 \mathrm{~m}$. Structure of the deposits is shown in

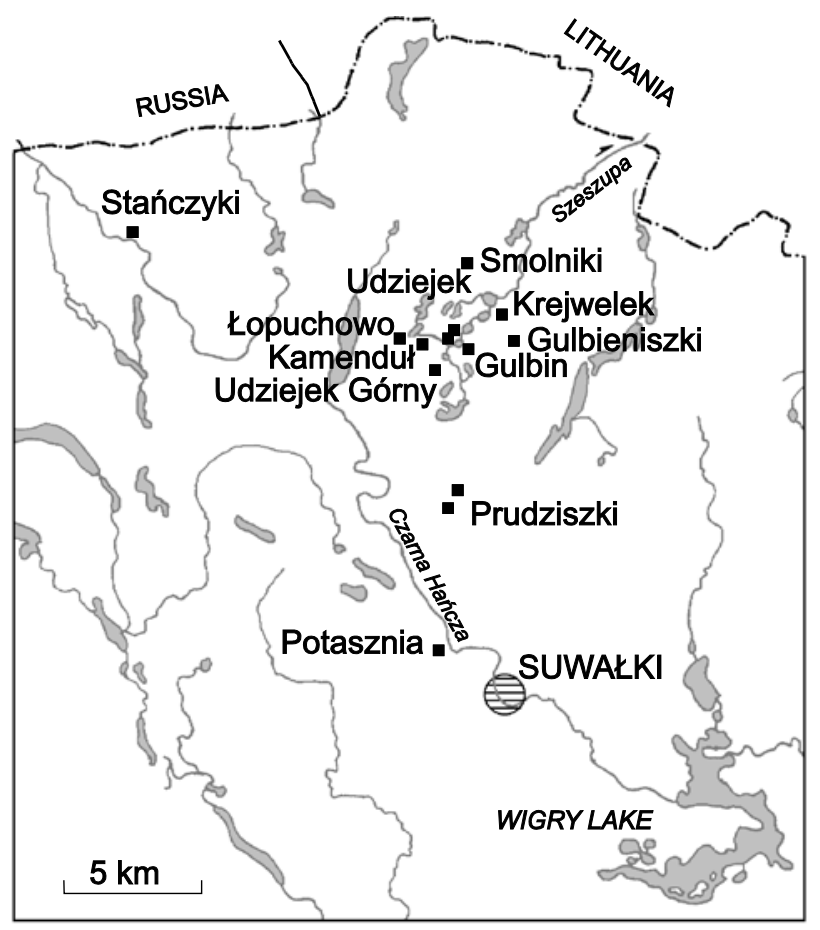

Fig. 1. Location of study sites
Fig. 2. Most frequently, they are composed of mixed sands, locally with an admixture of fine gravel or silt and clay. In general, three sedimentary units can be distinguished within the deposits. The lowermost (oldest) unit is $20-50 \mathrm{~cm}$ thick with horizontal layering or lamellar structure and flow structures in places. The next unit, 20$50 \mathrm{~cm}$ thick, is lamellar or massive with an admixture of organic matter. Usually, a fossil soil horizon can be found at the top of this unit. The uppermost unit, $60-120 \mathrm{~cm}$ thick, is a structureless homogenous sediment and includes dispersed humus and fine charcoal pieces. Lack of any sedimentary structures can be attributed to cultivation of the slope. The three units occur at the footslopes together in one sequence only locally. Usually, only two units or one (the uppermost) unit can be found at the footslopes.

The age of the colluvium triggered by human action usually correlates with archaeological data relatively well (Fig. 3). Significant variations in the age of the deposits relates to the settlement stages of the researched area and shows gradual enlargement of the deforested slopes by the Balts and then the Jatvings and during the last phase of the settlement in $15^{\text {th }}$ and $16^{\text {th }}$ century (Smolska, 2007; Smolska and Szwarczewski, 2009). However, in certain cases the radiocarbon age of the deposits does not correlate with archaeological data (Fig. 3). Such cases were closely analysed (Fig. 4).

\section{Lopuchowo - inverted age of the deposits}

Dating of fossil soil horizons can sometimes produce inverted age. Most of the attention was paid to archaeological artefacts of different age found in one sediment layer and to development of soil horizons. Sedimentological features of the deposits were usually disregarded.

The structure of the slope cover in Łopuchowo, $1.5 \mathrm{~m}$ thick, is shown in Fig. 2. The lower unit of the colluvium is composed of sands with no organic matter. Some flow structures can be observed at the floor and layering at the top of the unit. Thickness of this unit is only $35-40 \mathrm{~cm}$. Gradual increase of the organic matter content (from $0.2 \%$ to $1.5 \%$ ) is observed in the middle unit of the colluvium (Fig. 4A). Fossil soil horizon (c. 3\% OM) occurs at the top of this unit, at the depth of $80-90 \mathrm{~cm}$. The soil is dated at $2740 \pm 70 \mathrm{BP}(\mathrm{Ki}-10281)$. The structureless sediments deposited above the fossil soil originated from intensified soil erosion after forest clearance. Their sorting is worse due to admixtures of silt and clay. Organic matter content is $2.5-3 \%$, and up to $3.5 \%$ in layers enriched with humus at the depth of $60-70 \mathrm{~cm}$. This humusrich layer was dated at 3160 $\pm 90 \mathrm{BP}$ (Ki-7962) which produced the inversion in comparison with the fossil soil horizon occurring underneath. The dated humus-rich layer has the highest electrical conductivity, even higher than the contemporary tillage horizon. This can be explained by high content of humus, clay fractions and colloidal substances derived from the erosion of the upper parts of the slope. The enrichment in fine material is also 

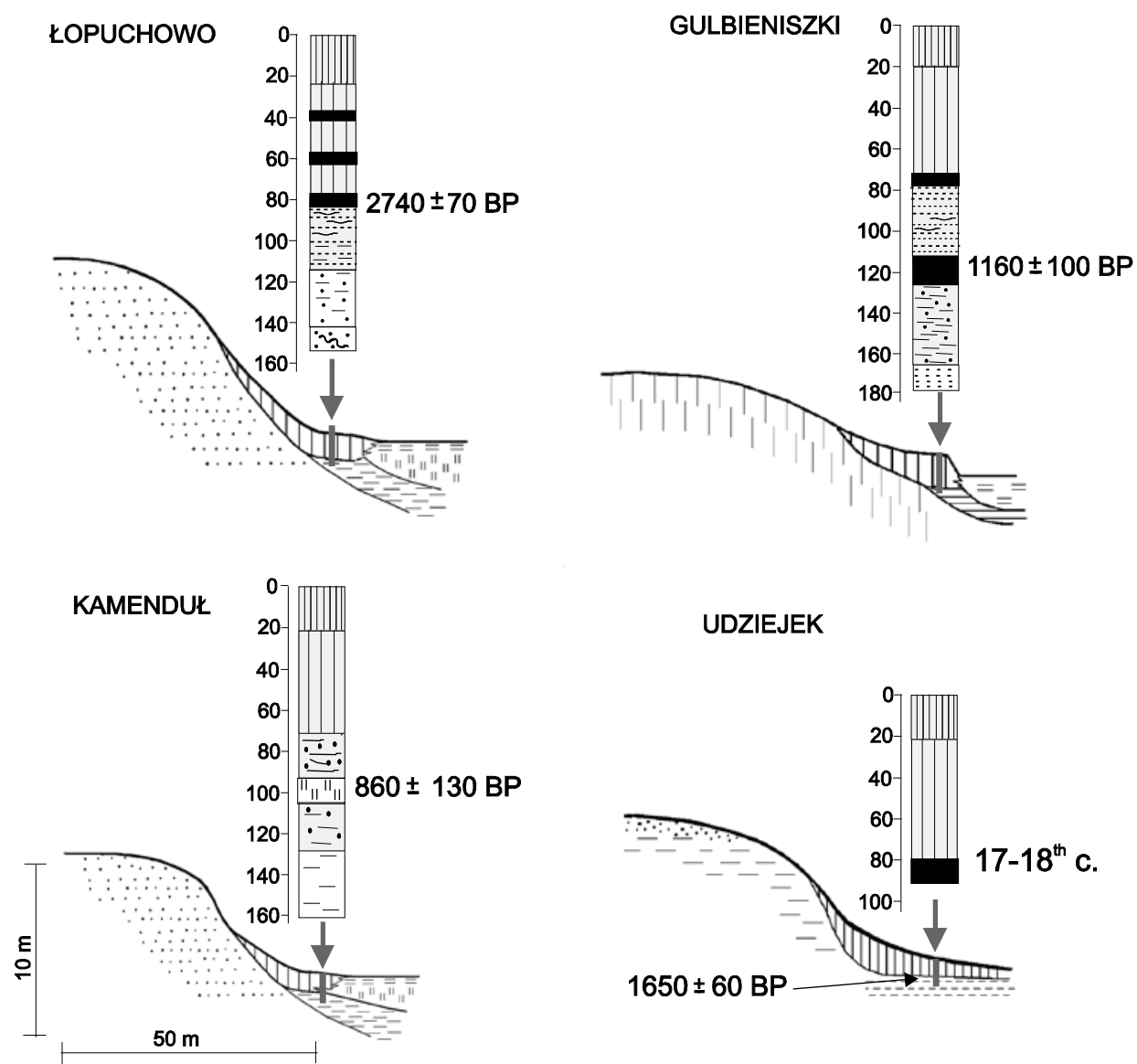

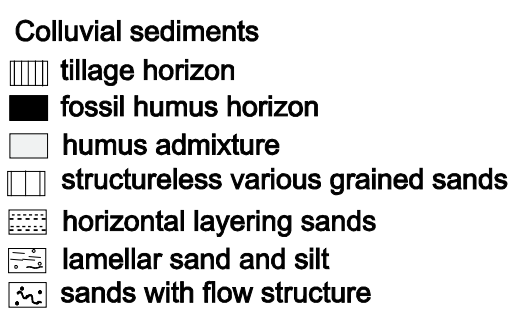

Fig. 2. Selected slope profiles and colluvial deposits at footslopes

reflected in granulometric indices - the mean grain size diameter $\mathrm{Mz}=2.8$ phi and the worst sorting $\sigma_{1}=0.8$ (apart from the tillage horizon).

A content of heavy minerals within the footslope deposits was analysed at the Łopuchowo site (Fig. 4A). The layer of inverted age $(3160 \pm 90 \mathrm{BP}, \mathrm{Ki}-7962)$ has an abundance of mica (12\%) and amphiboles $(28 \%)$ and a significant share of pyroxenes $(3.5 \%)$ in comparison with the layer dated at $2740 \pm 70 \mathrm{BP}(\mathrm{Ki}-10281)$, having the share of the same minerals: $9.8 \%, 24 \%$ and $5 \%$ respectively. Micas are easily mobilized and transported due their lamellar structure, therefore relative abundance of micas is characteristic of the depositional zone (Racinowski, 1974, Florek et al., 1987, 1990; MycielskaDowgiałło, 1995, 1999). Amphiboles are resistant to mechanical abrasion but not for chemical weathering, therefore these minerals are poorly represented in soil horizons (Konecka-Betley and Majsterkiewicz, 1973; Kuźnicki et al., 1974; Cichosz-Kostecka et al., 1991). Therefore, the higher number of amphiboles in the layer of inverted age can be interpreted as a result of a limited action of soil forming processes. Pyroxenes are also not resistant to chemical weathering; they differ from amphiboles in slightly higher resistance to abrasion. When analyzing processes of transport and deposition, one should take into consideration the proportion between amphiboles and pyroxenes. Lower values of the $\mathrm{A} / \mathrm{P}$ index, the number of amphiboles divided by the number of pyroxenes, are typical for fossil soil horizons found within dunes (Barczuk and Mycielska-Dowgiałło, 2001). Apparently, this index can be also used in the analysis of the colluvial deposits. It attains lowest values in the lower 

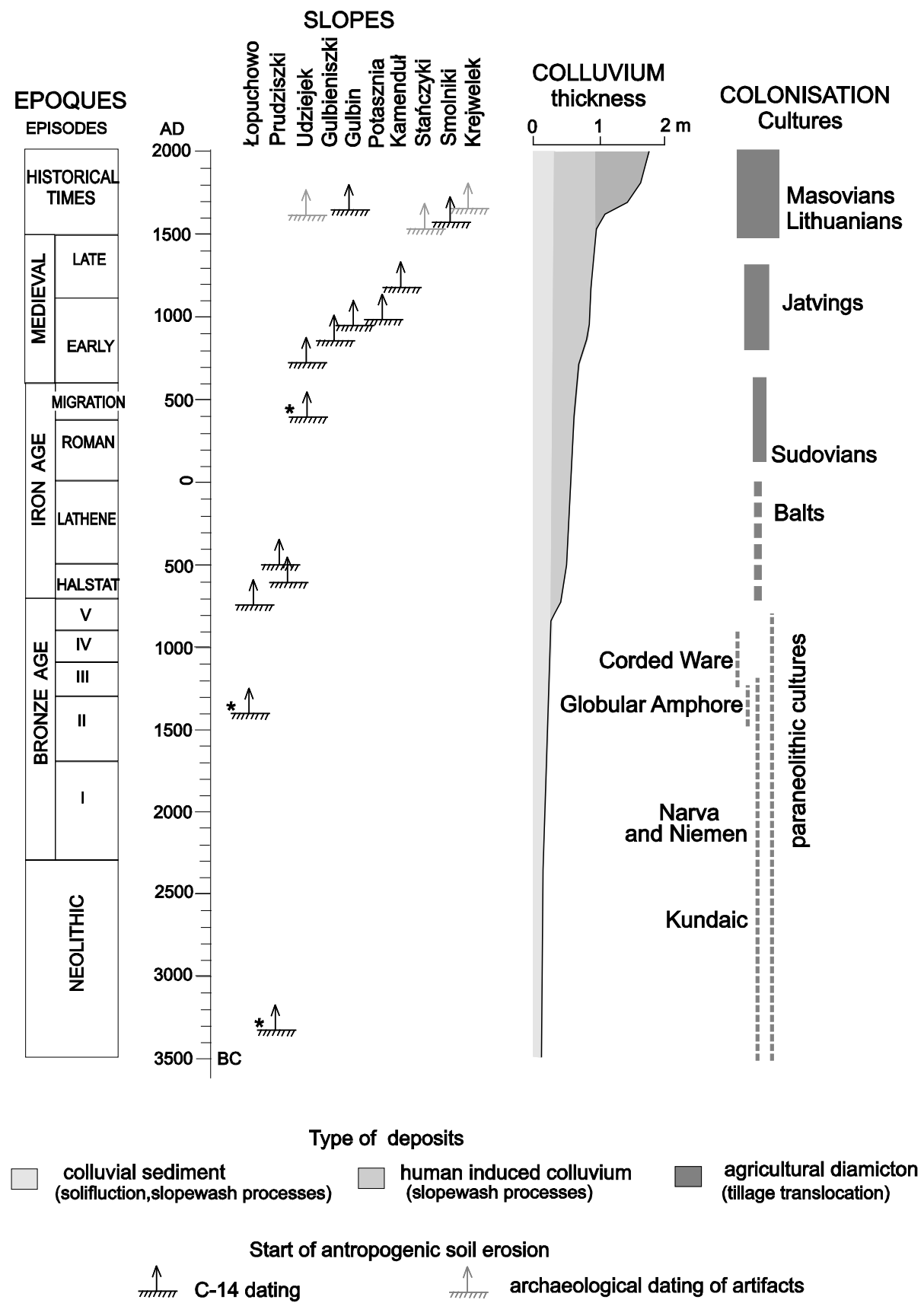

Fig. 3. Comparison of the age and thickness of anthropogenic colluvial sediments with colonisation phases of Suwakki Lakeland according to regional scale (Kaczanowski and Kozłowski, 1998; Brzozowski et al., 1993, Bitner-Wróblewska, 1998); (“discussed age of colluvium)

humus horizon (dated 2740 $\pm 70 \mathrm{BP}, \mathrm{Ki}-10281$ ). On the other hand, the value of this index calculated for the layer of the inverted age is not outstanding (Fig. 4A).

Complex analysis of the sedimentological features (granulometry and heavy minerals content) allows to determine phases of slope stabilisation and aggradation in cases where fossil humus horizons are similar and the colluvial deposits do not differ when examined in the filed.

\section{Prudziszki - degradation process recorded in the deposits}

A case from the Prudziszki site was selected in order to show how the degradation process is recorded within the deposits. At this site, peat found under colluvium is dated at $5405 \pm 80 \mathrm{BP}(\mathrm{Ki}-10280$, Fig. 4B), which is an extraordinary old age and completely does not correlate with archaeological data, since the first farmers arrived to the study area much later. Age of the peat neither agrees 


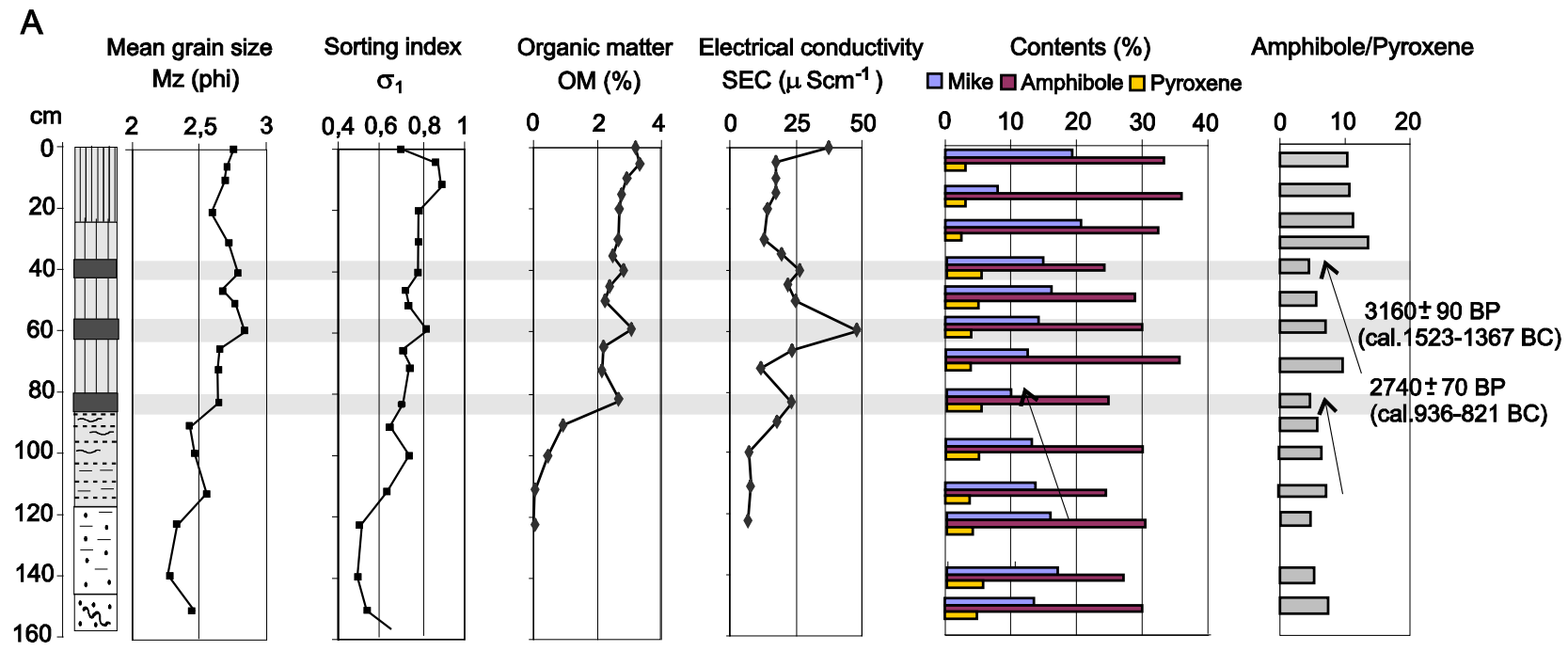

B

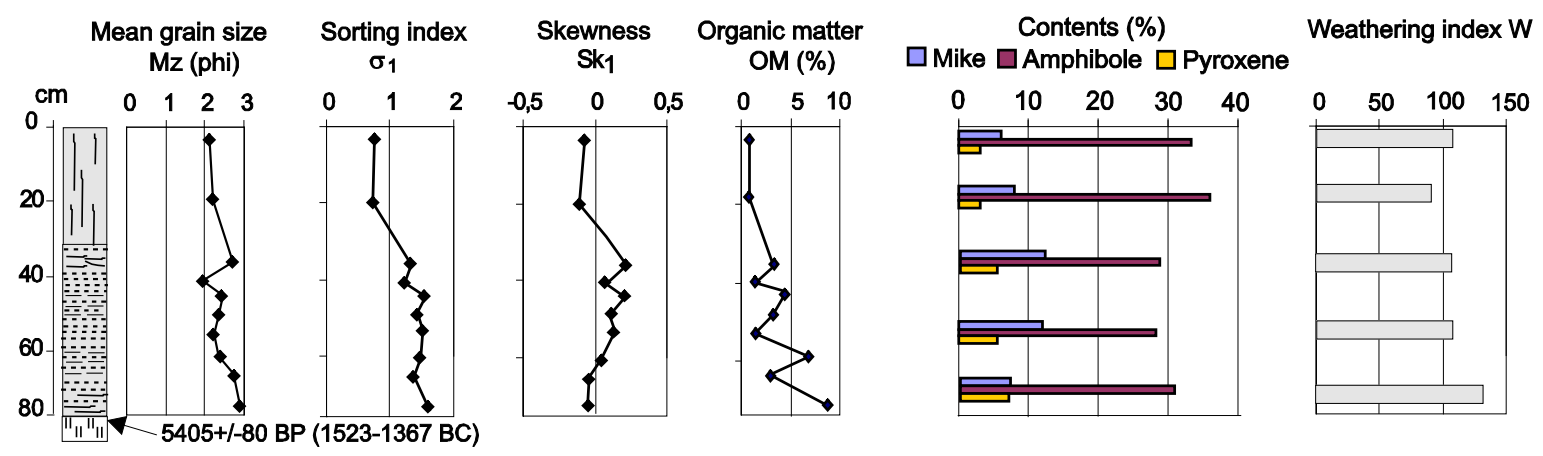

C
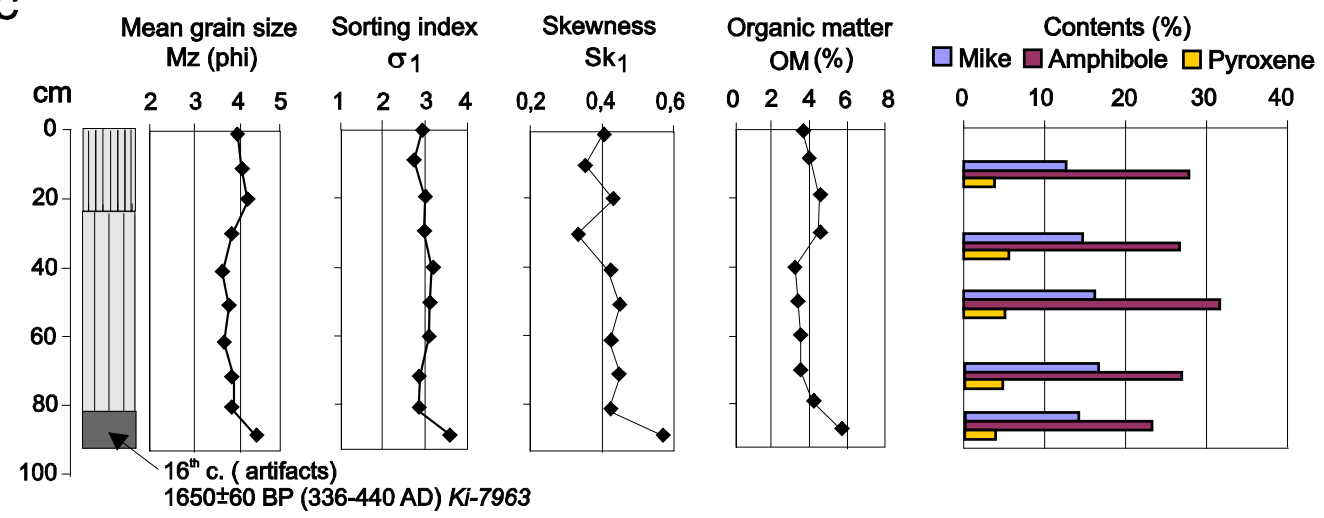

Weathering index $W$
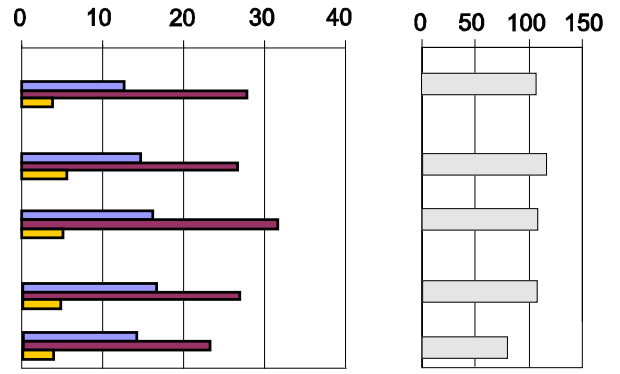

Fig. 4. Chosen sediment characteristics at vertical colluvium profiles: Łopuchowo (A) Prudziszki (B) and Udziejek (C); arrows show weatheringdepositional cycles; lithology explanation in Fig. 2.

with palynological data, because sediments of such age do not contain crop pollen (Stasiak 1965, 1971; Kupryjanowicz, 2004, 2007). The lower part of the colluvium deposited at the footslope is characterised by lightly higher organic matter content and finer fraction which is reflected in $\mathrm{Mz}$ (attaining higher value in the phi scale). The only untypical feature for the fossil soil horizon is a slightly negative skewness. It can be inferred that the lower part of the colluvium is not a typical soil horizon, despite its apparent similarity to hydromorphic soils (black soils).

The analysis of heavy minerals, with a special focus on the resistant minerals, is often used in inferring about the weathering processes (Mycielska-Dowgiałło, 1995, 
1999). Shares of minerals of different resistance to mechanical and chemical weathering are compared with each other and a weathering index $(W)$ is calculated. Racinowski and Rzechowski (1969) determined the value of the weathering index based on glacial tills of different age and described it as follows:

$$
W=S t \cdot \frac{N}{T}
$$

where $N$ is the percentage share of not resistant minerals, $S t$ - the share of minerals of moderate resistance, $T$ - the share of resistant minerals. This index was also used for fossil soil horizons found within the dune sediments (Konecka-Betley and Majsterkiewicz, 1973; CichoszKostecka et al., 1991; Dzierwa and MycielskaDowgiałło, 2003). Lower values of $W$ indicate chemical weathering, high values indicate mechanical weathering (abrasion). The value of the weathering index calculated for the colluvium at Prudziszki varies between 95 and 135 (Fig. 4B). In the lowermost part of the deposits, it attains the highest value (135), indicating mechanical erosion (abrasion due to transportation along the slope profile). Probably, the uppermost part of the underlying peat was eroded and therefore the extraordinary old age of the peat, older then the beginning of the Balts settlement in the area (at $8^{\text {th }}$ century BC), can be understood.

\section{Udziejek - sedimentary record of soil weathering}

Sometimes, in a single colluvial layer archaeological artefacts of different age can be found. Such artefacts could have been transported from the whole microcatchment area. In such cases, age of the youngest artefacts serve as an indicator of the time of colluvium deposition. Such a situation occurs in Udziejek where the whole colluvial deposits are structureless and homogenous, only their lowermost part is enriched in humus (Fig. 2). Artefacts of a diversified age (from Neolith up to the New Era times) were found within the deposits. The radiocarbon age of the lowermost part of the deposits is $1650 \pm 60 \mathrm{BP}$ (Ki-7963). On the other hand, the youngest archaeological artefacts show significantly younger age of the colluvium $\left(16^{\text {th }}\right.$ century AD).

Granulometric composition and content of heavy minerals in the vertical profile of the colluvium in Udziejek is shown in Fig. 4C. Weak sorting of the lowermost part of the colluvium and significantly positive skewness are indicative of aggradation processes. Low value of the weathering index $(W=75)$ usually testify for a long-lasting (slow) soil forming process. Very small share of amphiboles $(23 \%)$ can be interpreted as a remnant of an older soil horizon, developed before the cultivation of the slope. Tillage of the slope leads to mixing of the previous soil with younger slope deposits and creation of the mixed colluvium. The radiocarbon age probably shows the real date of start of denudation triggered by human action. This is supported by archaeological arte- facts from the Balts and the Jadvings cultures found in other places near the researched slope in Udziejek (Brzozowski et al., 1993).

\section{CONCLUSIONS}

Denudation triggered by the human action is a very dynamic process, and studies of late-Holocene deposits must take into account the settlement history of the area. Radiocarbon age of the colluvium originated from enhanced erosion sometimes does not correlate with archaeological data. This research on granulometric features and heavy minerals was focused on colluvial layers enriched in humus in three different situations: 1) occurrence of inverted age of the humus rich layers - record of aggradation process in sediment, 2) radiocarbon age being older then archaeological evidence - record of erosion process, and 3) record of older fossil soil transformed during younger phase of colonisation. It is found that analyses of sedimentological features of colluvium such as: share of fine fraction (or the mean grain size diameter), sorting, skewness, and organic matter content are useful tools in reconstruction of soil erosion phases. Electrical conductivity and content of heavy minerals determined for selected soil horizons allows inferring about degradation and agradation processes and therefore help in a proper selection of samples for dating. Sedimentological features of the deposits can be also used in reconstructing phases of slope erosion in places where archaeological dating is missing.

\section{ACKNOWLEDGEMENTS}

I would like to thank Prof. Elżbieta MycielskaDowgiałło and Prof. Andrzej Barczuk for a discussion on interpretation of heavy minerals analysis.

\section{REFERENCES}

Barczuk A and Mycielska-Dowgiałło E, 2001. Znaczenie składu mineralnego osadów dla rozpoznawania obecności procesów eolicznych (Significance of mineral composition of the sediments in aeolian processes identification). In: Mycielska-Dowgiałło E, ed., Eolizacja osadów jako wskaźnik stratygraficzny czwartorzędu. Pracownia Sedymenologiczna, Wydział Geografii i Studiów Regionalnych, Uniwersytet Warszawski, Warszawa: 39-42 (in Polish).

Bitner-Wróblewska A, 1998. Suwalszczyzna w okresie węrówek ludów (Suwałki region during Migration Pieriod). In: Karczewski M, ed., Ceramika zachodniobattyjska od wczesnej epoki żelaza do początku ery nowożytnej. Materiaty z konferencji - Białystok, 1416 maja 1997, Białystok: 305-318 (in Polish).

Bluszcz A, Poręba GJ and Śnieszko Z, 2007. The basis of the study of the age of the Holocene diluvium on less areas of Polish highlands. Geochronometria 28: 61-66, DOI 10.2478/v10003-007-0022-1.

Bork H-L, 1989. Soil erosion during the past Millennium in Central Europe and its significance within the geomorphodynamics of the Holocene. In: Ahnert F, ed., Landforms and landform evolution in West Germany. Catena Supplement 15: 121-131.

Brzozowski J, Iwanowska G, Okulicz-Kozaryn J and Siemaszko J, 1993. Dzieje zasiedlenia Suwalszczyzny od epoki kamienia do 
wczesnego średniowiecza (Settlment of Suwałki District from Ston Age to early Medieval). In: Przewodnik LXIV Zjazdu PTGeol. na Ziemi Suwalskiej 9-12. 09. 1993: 108-126 (in Polish).

Cichosz-Kostecka A, Mycielska-Dowgiałło E and Manikowska B, 1991. Late glacial aeolian processes in the light of sediment analysis from Kamion profile near Wyszogród. Zeitschrift für Geomorphologie, Neue Folge, Supplement 90: 45-50.

Dzierwa K and Mycielska-Dowgiałło E, 2003. Rekonstrukcja dynamiki procesów eolicznych i czasu ich trwania na podstawie wybranych cech teksturalnych osadów wydmy w Ciẹciwie (Reconstruction of aeolian processes dynamic and their duration based on chosen sediment features of dune in Cięciwa). Przeglad Geologiczny 51(2): 163-167 (in Polish).

Florek W, Florek E and Mycielska-Dowgiałło E, 1987. Morphogenesis of the Vistula valley between Kępa Polska and Płock in the Late Glacial and Holocene. In: Starkel L, ed., Evolution of the Vistula River Valley during the last 15000 years. Special Issue 4. Ossolineum, Warszawa: 189-205.

Florek W, Mycielska-Dowgiałło E and Starkel L, 1990. Lithology and facies of fluvial deposits. In: Starkel L, ed., Evolution of the Vistula river valley during the last 15000 years. Part III. Geographical Studies, Special Issue 5: 111-126.

Folk RL and Ward W, 1957. Brazos River bar: a study in the significance of grain size parameters. Journal of Sedimentology and Petrology 27: 3-26.

Kaczanowski P and Kozłowski JK, 1998. Wielka historia Polski, T. 1. Najdawniejsze dzieje ziem polskich (do VII) (Great history of Poland. The oldest history of Polish territory. Fogra, Kraków: 382pp (in Polish).

Kalicki T, 2006. Zapis zmian klimatu oraz działalności człowieka i ich rola $\mathrm{w}$ holoceńskiej $\mathrm{w}$ ewolucji dolin środkowoeuropejskich (summary: Reflection of climatic changes and human activity and their role in the Holocene evolution of Central European valley). Prace GeograficzneIGiPZ PAN 204: 348 pp (in Polish).

Klimek K, 2003. Sediment transfer and storage linked to Neolithic and Early Medieval soil erosion in the Upper Odra Basin, southern Poland. In: Howard AJ, Macklin MG and Passmore DG, eds., Alluvial Archaeology in Europe. A.A. Balkema Publications: 251-259.

Konecka-Betley K and Majsterkiewicz T, 1973. Geneza gleb wytworzonych z pokrywowych utworów pyłowych Polski środkowej (Origin of soils formed on silty sediments covers in middle part of Poland). Roczniki Gleboznawcze 24(2): 133-158 (in Polish).

Kupryjanowicz M, 2004. Postglacjalny rozwój roślinności rejonu jeziora Wigry. Wstępne wyniki analizy pyłkowej osadów dennych z Zatoki Słupińskiej (abstrakt: Postglacial development of vegetation in the Lake Wigry vicinity. Preliminary results of pollen analysis of deposits from Słupiańska Bay. Rocznik AugustowskoSuwalski IV, Suwałki: 37-44 (in Polish).

Kupryjanowicz M, 2007. Postglacial development of vegetation in the vicinity of the Wigry lake. Geochronometria 27: 53-66, DOI 10.2478/v10003-007-0018-x.

Kuźnicki F, Białousz S, Rusiecka D and Skłodowski P, 1974. Charakterystyka procesu bielicowienia $\mathrm{w}$ glebach wytworzonych $\mathrm{z}$ piasków wydmowych Puszczy Kampinoskiej (Podzolic process characteristic for dune sandy soils in Kampinos Forest). Roczniki Gleboznawcze 25(2): 25-51 (in Polish).

Lang A, 2003. Phases of soil erosion derived colluviation in the loess hills of South Germany. Catena 51(3-4): 209-221, DOI 10.1016/S0341-8162(02)00166-2.

Lang A and Hönscheidt S, 1999. Age and source of soil erosion derived colluvial sediments at Vaihingen-Enz., Germany. Catena 38(2): 89-107, DOI 10.1016/S0341-8162(99)00068-5.

Mycielska-Dowgiałło E, 1995. Wybrane cechy teksturalne i ich wartość interpretacyjna (summary: Selected textural features of deposits and their interpretation). In: Mycielska-Dowgiałło E and Rutkowski J, eds., Badania osadów czwartorzędowych. Wybrane metody $i$ interpretacja wyników. Wydawnictwo WGiSR UW, Warszawa: 29-105 (in Polish)

Mycielska-Dowgiałło E, 1999. Analiza zawartości minerałów ciężkich w osadach stokowych na przykładzie stoku w Łopuchowie (Analysis of heavy minerals composition in colluvial deposits on exam- ple of hillslope in Łopuchowo). In: Dynamika procesów stokowych $i$ fluwialnych $w$ rzeźbie mtodoglacjalnej $w$ świetle wybranych cech sedymentologicznych. Materialy warsztatów terenowych $w$ Jeleniewie k/Suwatk 13-17.09.1999, Wydawnictwo WGiSR UW: 6667 (in Polish).

Pazdur A, 2007. Oznaczanie wieku osadów metodami izotopowymi i dozymetrycznymi (Sediment age determination based on isotope and dosimetric methods). In: Mycielska-Dowgiałło E and Rutkowski J, eds., Badania cech tekstualnych osadów czwartorzędowych $i$ wybrane metody oznaczania ich wieku. Wydawnictwo SWPR w Warszawie: 251-279 (in Polish).

Pazdur M, 1995. Oznaczanie wieku osadów metodami izotopowymi (summary: Isotope age determination of Quaternary sediments). In: Mycielska-Dowgiałło E and Rutkowski J, eds., Badania osadów czwartorzędowych. Wybrane metody $i$ interpretacja wyników. Wydawnictwo WGiSR, Warszawa: 29-356 (in Polish).

Racinowski R, 1974. Dynamika środowiska sedymentacyjnego strefy brzegowej Pomorza Zachodniego w świetle badań minerałów ciężkich i uziarnienia osadów (Dynamic of coastal sedimentation environment in the light of heavy minerals studies and grain-size sediment composition). Prace Naukowe Politechniki Szczecińskiej, Instytut Inżynierii Wodnej 4: 87 pp (in Polish).

Racinowski R and Rzechowski J, 1969. Minerały ciężkie w glinach zwałowych Polski środkowej (Heavy minerals in glacial tills of middle Poland). Kwartalnik Geologiczny 13(2): 479-490 (in Polish).

Reimer JR, Baillie MGL, Bard E., Bayliss A., Beck JW, Bertrand CJH, Blackwell PG, Buck CE, Burr GS, Cutler KB, Damon PE., Edwards RL, Fairbanks RG, Friedrich M, Guilderson TP, Hogg AG, Hughen KA, Kromer B, McCormac G, Manning S, Ramsey CB, Reimer RW, Remmele S, Southon JR, Stuiver M, Talamo S, Taylor FW, van der Plicht J and Weyhenmeyer CE, 2004. INTCAL04 terrestial radiocarbon age calibration, $0-26 \mathrm{cal}$ yr BP. Radiocarbon 46: 1029-1058.

Sinkiewicz M, 1993. Rola denudacji antropogenicznej w przeobrażeniu stoków i gleb w środkowej części Polski północnej (summary: Significance of anthropogenic denudation in the transformation of slopes and soils in middle part of northern Poland). In: Kostrzewski A, ed., Geoekosystem obszarów nizinnych. Zeszyty Naukowe Polskiej Akademii Nauk „Człowiek i środowisko” 6: 153-158 (in Polish).

Sinkiewicz M, 1998. Rozwój denudacji antropogenicznej w środkowej części Polski północnej (summary: The development of anthropogenic denudation in central part of northern Poland). Wydawnictwo UMK, Toruń: 1-103 (in Polish).

Smolska E, 2003. Cechy sedymentologiczne osadów stokowych na przykładzie pagórka w Łopuchowie (Pojezierze Suwalskie) (summary: Sedimentological features of the colluvial deposits on example of the slope cover of the hillock in Łopuchowo area (Suwalskie Lakeland). Warszawa, Prace Geograficzne WGSR UW 33: 45-57 (in Polish)

Smolska E, 2005. Znaczenie spłukiwania w modelowaniu stoków młodoglacjalnych (na przykładzie Pojezierza Suwalskiego) (summary: Slope wash processes in late glacial area on example of $\mathrm{Su}-$ wałki Lake District). WGSR UW, Warszawa: 1-146 (in Polish).

Smolska E, 2007. Development of gullies and sediment fans in lastglacial areas on the example of the Suwałki Lakeland (NE Poland). Catena 71(1): 122-131, DOI 10.1016/j.catena.2006.10.009.

Smolska E and Szwarczewski P, 2009. Antropogeniczne uwarunkowania rozwoju pokryw stokowych na Pojezierzach Suwalskim i Sejneńskim (abstract: Slope covers response to human activity on Suwałki and Sejny Lakelands). In: Domańska L, Kittel P and Forysiak J, eds., Środowiskowe uwarunkowania lokalizacji osadnictwa, Ser. Wyd. SAS, Środowisko-Człowiek-Cywilizacja t. 2, Wydawnictwo Bogucki, Poznań: 354-363. (in Polish)

Starkel L, 1988. Działalność człowieka jako przyczyna zmian procesów denudacji i sedymentacji w holocenie (Man's activity as a cause of changes of denudation and sedimentation processes in the Holocene). Przegląd Geograficzny 60: 251-265 (in Polish). 
Starkel L, 2005. Anthropogenic soil erosion since the Neolithic in Poland. Zeitschrift für Geomorphologie, Neue Folge, Supplement 139: 189-201.

Stasiak J, 1965. Badania nad starożytnym krajobrazem Pojezierza Suwalskiego w rejonie Szwajcarii (Researches on ancient landscape of Suwałki Lake District in the Szwajcaria Region). Prace Białostockiego Towarzystwa Naukowego 7: 1-42 (in Polish).

Stasiak J, 1971. Holocen Polski pótnocno-wschodniej (The Holocene of North-Eastern Poland). Rozprawy UW, Warszawa: 110 pp (in Polish).

Stuiver M and Reimer PL, 1993. Extended ${ }^{14} \mathrm{C}$ database and revised CALIB radiocarbon calibration program. Radiocarbon 35: 215230.

Śnieszko Z, 1991. Reflaction of extreme events in evolution of dry valley in loess Roztocze Upland. In: Jersak J., ed., Less $i$ osady dolinne. Prace Uniwersytetu Śląkiego 1107: 119-129.

Śnieszko Z, 1995. Ewolucja obszarów lessowych Wyżyn Polskich w czasie ostatnich 15000 lat (summary: The loess cover evolution during last 15,000 years in Polish Uppland). Wydawnictwo UŚ, Sosnowiec: 122 pp (in Polish).

Twardy J, 2002. Etapy neoholoceńskiej ewolucji suchych dolin denudacyjnych na Wyżynie Łódzkiej w świetle analizy osadów (Neoholocene evolution stages of dry valley on Łódź Upland based on sediment analysis). Acta Universitstis Nicolai Copernici, Geographica 32- Nauki Matematyczno-Przyrodnicze 109: 127-137 (in Polish).

Wilkinson KN, 2003. Colluvial deposits in dry Valley of Southern England as proxy indicators of paleoenvironmental and land use change. Geoarchaeology 18(7): 725-755, DOI 10.1002/gea.10090.

Zolitschka B, Behre K-E and Schneider J, 2003. Human and climatic impact on the environment as derived from colluvial, fluwial and lacustrine archives - examples from the Bronze Age to the Migration period, Germany. Quaternery Science Reviews 22: 81-100, DOI 10.1016/S0277-3791(02)00182-8. 